\title{
STUDIES ON THE ROLE OF SHELLFISH AS A SOURCE FOR TRANSMITTING SOME PARASITES OF ZOONOTIC IMPORTANCE
}

\author{
Mohamed, A. A.; Magda, A. Amin; \\ Amer, O. H.* and Amln, A. M. \\ Deparlment o Zoonuses. Faculiy of Velcrimary Mediche. Zagazig Universliy.

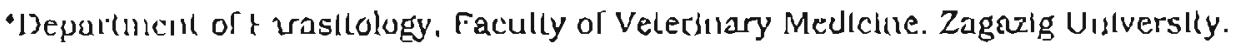

\begin{abstract}
The present shudy wus cunducled to chanify the ole of shellfish as a source for

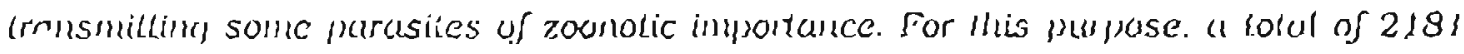

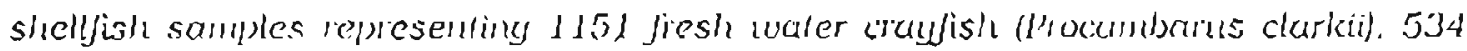
whlle shrimps (benuens seliferus) and 400 blue crabs (Callinecles subidus) were collecled Jrom Sharkia. EL-Ismalla and Porl Said Proubices and examinci for Ire presence of tremalode melacercariae and protozual oocysts or cysts. The icsults revealed that the infection rates of encysted melacercarlae in the examined shellfish were $79.93 \%$, $52.06 \%$ and $38.7 \mathrm{ci}$ in craysish, shrimps and crabs. respectively. The encysied melacercarlae recovered from craldish were belongung to four famllies of Holerophlyidae. Nicro-

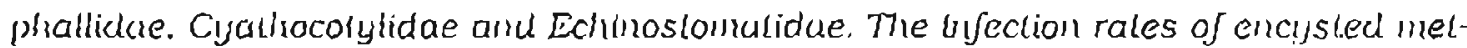
acercariae in shrinys in Sharkia. EL-Ismalia and Port Said Provinces were 48.76\%. $54.04 \%$ and 52.87\%, respectively. The oblained melacercuriae ivere belonging to three familles of helerolihyldae. Microphallidae and Cyathocolylidae. The rales of crabs in. fectlon will unldenlified encysled melacercariae were 28.28\%, 43.9\% and 42.85\% in Sharkia. El-Ismalia and Port Said Provinces. respectively. Regarding the seasonal prevalence of encysted melacercariae in examined crayfist. The peak of infection (93.79\%) was delected in summer follcwed by spring (75.6\%), auhum (74.9\%) and the lowest onc was obsenved in winler (27.27y6). One liundred und fify six adull worms of len tremalode species were developed ufer experimental infection of sixleen puppies

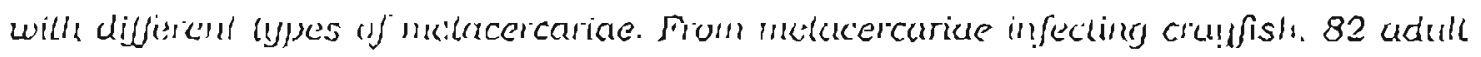

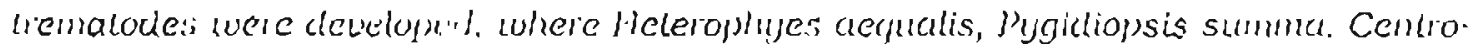

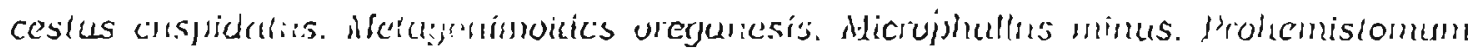

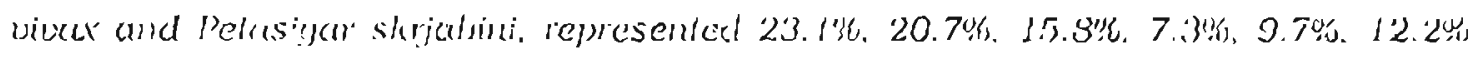

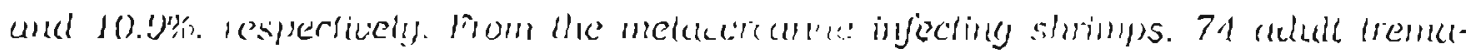


lades were developed. Of Uhese Irematodes: Heterophyes aequalis. Pygldiopsls genala, Cenirocestus cispldalus, Microphallus minus, Maritrema kitanesis and Prohemistomatid sp.; represenled 24.3\%, 18.9\%. 21.6\%. 21.6\%. 4.05\% and 9.4\%, respeclively. On the other hand, melacercariae infecling crabs usere not able to develop adult tremalodes in the experimentally infecled pupples unill 128 day posturfection (PI). Concerning the occurrence of prolozoa cocysts or cysts in sizellish, vie percentages of recovered Cryptospordium parum oocyst and Giardia sp. cyst were $9.29 \%$ and $4.77 \%$, respechuely. while, all examilied slirimp and crab samples were free from uyfection. Experimental in. Sections of fwe while albino rats with Cryptusporidium parum vocysts of crayfish origin revealed that four (80\%) rats were infecled, of which, one shed oocysts at $3^{\text {rd }}$ day $P$. whlle. the remainder lhree infected rats shed the oocysts th their Jaeces at $5^{\text {th }}$ day Pl. On the olier hand. (wo experimentally infected pupples with Giurdiu sp. cysls of crayssh origin slied the infective slage in their faeces at $7^{\text {th }}$ day $\mathrm{rl}$. Hislovalliological examulation of inlestinal seclions of experimentally infected anumals revealed hisiopalhological reaclions due 10 effect of trematodes and protozoa. coglher with developmental slages of Cryplusporldium parum and Glardia sp. Il could be concluded that shellfish harbored many trematodes and protozoal agents transmissible lo man. Zoonolic inportance of recovered tremalodes and prolozoa was fully discussed.

\section{INTRODUCTION}

Shellnsh is becoming to be an increasingly iniportant sealood. About 70 specics of intestinal nukes of nsh and shellnsh urigin have been reported to infect people. Uhese flukes belong to fam-

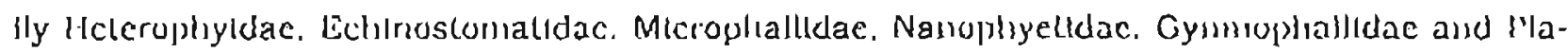
gluschlidae. People contract the infection through cating raw or improperly prepared nsli and crustaceans infected will encysted metacercarlae (Hal and Mott, 1994). The public health and economlc inipact of nsh and shellnsh-borne parasitic zoonoses is considerable in terms of norbldily and even martally in human as well as In losses due to condenmation of parasillzed nish and sliellnsh. Accordingly to the (WHO. 1996), Ish or crustacean borne-lremalodes (spectes of Intestunal Rukes. Clonorchis. Oplshorchls and Yaragonimus) Infect 39 mzllion people and 550 million are at risk. Most of these Infection occur in Asla, pardcularly the Far Cast and Snuth Cast Asla.

Helerophylasis is an inlestunal infection, endemle in many localltes in Egypt. Heavy Infection can cause abdominal paln and dlarrhea. The transmisslon of helerophylasis in Egyph is conlinuous especially in lakes with brackisl water (Abou-Basha et al., 2000). 
Echinostomiasls is a zoonotic disease. endemic in many countrles especlally those in the South East Asla and Far East, where the human infections are assoclated with common sociacultural practices of eaung raw or Insumclently cooked crustaceans, hsh and mollusks (Graczyk and Fried. 1998).

Shellish have the ablity to carry and concentrate human waterborne pathogens such as Cryptosportdium and Clardla in thetr gills and Ussues through absorption of protozoal agents from contaminated water with human and anilual excreta (Fayer et al., 2003).

Since the Introduction of fresh water craynsh. Procambarus clarkil in the early 1980 s into the Egypuan fresh water systems for aquaculture from the Uniled States of Amerlca (Rawh, 1996), is lias been rapidly expanded In all aquatic ecosystems including streams. ponds and marshes wilh polluted or clean waters. P. clarkil becomes successfully adapted to the new habltats and become an important compound of the local dquallc fauna (Pbrahlm et al., 1995). P. clarkil stands as an Important food in many parts of the world, belng a rich source of proteln. In Egypt. It has teen consumed in lew areas, belng cheaper than other crustzcean. in Egypt. Where are few studles carrled uut to verlfy the role of fresh water craylish in transmission of parasites (Fagek et al., 1999 and Raef et al., 2003). Therelore. to clartfy the role of shellish in transmitung some parasites of zoonolic Inportance, this work was undertaken to investigate the occurrence of trematode unetacercartae in shellnsh and experimental infection of puppies will recovered metacercartae to determine the adult trematode species. Aiso the occurrence of protozoa in shellissh and experimental infection of pupples and rats wh different isolated protozoal stages was carrled out.

\section{MATERLAL AND METHODS}

\section{A) Shellinh ramples:}

A total of 2181 shellnsh were collecled from Sharkla, EL-Ismalia and Port Sald Provinces. These included 1151 (resh water craynsh. 534 while sinmps (Penaeus seliferus) and 496 blue crabs (Callinectes sabidus) and surveyed for encysted metacercarlae and protozoa cysts or oocysts. Crayfls!' were collecied from different canals of Zagazig. Abokebeer. Hehla and Menja EL Kamah at Sharkla Province from the perlod extending from Aprl 2004 Ull February 2005. "The collecled shrimp samples included 162 from Zagazlg city at Sharkja. 198 from EL-Ismalla and 174 from Port Sald, nicanwlille, the collected crab sainples Includeu 152 crabs from Zagazig. 148 from EL-lsmalla and 196 from Port Sald. Shrinps and crabs were collected rrom Msh markets Irom the pertod extending from December 2004 lo May 2005. Ni samples of shellish were packed in plasuc bags contalning ice and sent fresh to Zoonoses Departinent. Faculty of Vetert- 
nary Medicine. Zagaz!g Unlverslty for parasitological examinations.

\section{B) Paragltological examination:}

Each shellinsh was frsuly examined macroscoplcally by naked eye and by the ald or magnifyIng hand lens anter the removal of the carpace to detect any changes in the viscera, cephalothorax and musculature. The delected metacercarlae were recovered from infected shellinsh accordIng to Mahdy et al. (1995). Thereafter, the microscopic examinations were done as follows; the gills, heart, midgut glands, muscles and tissues which adhered to the Inner surface of carpace were separately compressed between two slides and examined under dissecting inlcroscope (Suglgama et al., 2004). and also, the whule muscles, gills and ussue of each examined shelinish were digested in the aruficlal digesuve julce. Arter digestion, the sedinient was exainined under intcroscope and encysied Int tacercartae were collected and counted par each shellnsh. A part of the obtained encysted melacercarlae was used for experimental infcctiun of pupples and aiso a micropholo was done for each lyjo of encysted netacercariae (Garcla, 2001). The number un recuvcred melacercarlae from s:raylish in each seusun was also recordrcl. The presence of proluzoa vocysts or lysis ivas detccled in homiogeinized solt bissue. viscera and cephalothorax of each slillnsh by uslng cove. slip lloulallon w/th Sheatier's sugar solution (Levine, 1986).

\section{C) Expertmental Infections:}

\section{Experimental iafection of puppi:s with encysted metacercantac to develop adult trematodes.}

Nineteen pupples. of 4 weeks uld. rearesi on mllk and bread, werc used. 'Iwelve were expen-

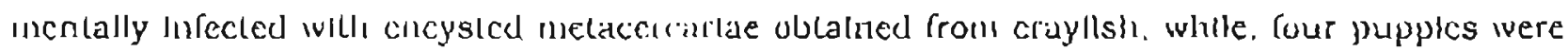

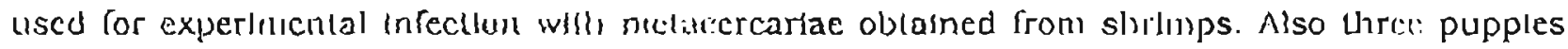
were experimentally infecled w/U, netaceicarlae obtalned from crabs. Faccal sainples were examined tulce weekly lup two weeks before Infection tu exclude any possible Infection with Inlest11d) parasiles by simple and sedimentation tecloniques (Happich and Boray. 1969). Also a propluylaclic dose of antlicllulıllc drug. Prazlquantel, 50mg/l okg B.WT., was given one week before experlinental infecilon and the pupyles were kept under sustable hyglestc measures. Pupples in-

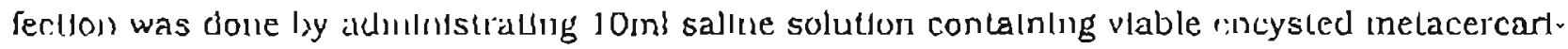

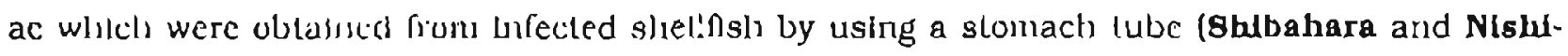
da. 1986). Nfler onc werk of infectlon, dally faecal examinnton was done by dircel and simple

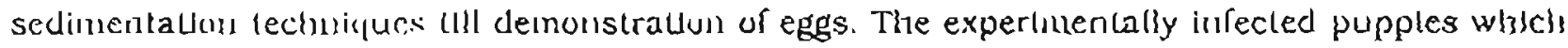

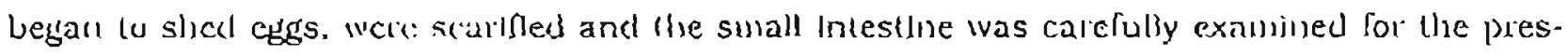
ence of a(luit Ibukes (Relu, 1962). Jn pupples in which no eggs were detecled in llie faeces, the 
lungs, livers, dlaphragm and body cavity were examined for Immalure tremalodes. The worms were collected. Rxed. stained and mounted according to Bi aicr et al. (1984) and Tantawy (1993). Idenufication of the recovered trematodes was carrled out depending on some characterIstlc morphological (')terla according to Yamagutl (1958). Shalaby (1982), Raef (1994) and Saba (2004).

\section{Experimental Infection of white alblno rats with Cryptosporidium parvum oocysts:}

Eight weanlng white albino rats were oblained from Faculty or Veterinary Mediclne, Zagazlg Unversity and tested to ensure thelr freedom from protozoal Infection. The isolated C. parvum oocysts were collected. suspended in $2.5 \%$ Potassium dichroriule solution. sleved and then sporulated by aerauton for one week at room temperalure. The sporulated C. parvum oocysts were concentrated by Sheather's sugar solution, and washed In de-lonized water by centrifugation. Five rats were inoculated orally by using sinall slonach tube wilh 0.211 of the concentrated Cryplosporddium suspension recuvered from crayfish, whlle. the I malning three rats were left as a control (Reese et al. 1982). Dally examinatlons of faecal pellets of all rats for one week before experimental Infection and for $1-18$ days posunfection (PI) for experimentally infecled rals by coversllp hoatation using Sheabler's sugar soluton. Also rats-faecal sinears were prepared, air dned then stanned using the inodifled Zlehl-Neelsen Lechuqque (Ht:riksen and Pohlenz, 1981). and examined inlcroscuplcally to detect C. parnum oocysts.

\section{Experimental Infectlon of puppies with Glardla sp. eysts.}

Three pupples of 4 week old were used. Glardia sp. cysts ubtatned from naturally infected craynsh were concentrated. and $0.2 \mathrm{ml}$ of Glardla cysts suspension were orally Inoculated to each of two puppies, but the remaining one puppy was left as a control (8iam et al., 1994). Dally examination of faecal materlal was camed out to determine the prepatent period.

\section{D) Histopathological examinatlons:}

Small portions of small Inlestnes of Infected pupples with encysled inftacercariac obtalned from craynsh and shrimps, sinall portion of duodenum of unfected puppy with Glardla sp. cysts recovered from crayflsh and small parts of lleun of infected rat will, C. parvum oocyst recovered from crayflsh, were Ixed II 10\% buffered formalin then embec'ded in paramn wax blocks, thereafler, sectioned at $5 \mu$ and stalned with Hemaloxylin and Eosth. These secilons were examined microscopically to study the pathological changes due to the effect of adult worns and develop- 
mental stages of protozoa on thelr hosts according to Reese et al. (1982), Ibrablm et al. (1989) and Fayer et al. (1997).

\section{DISCUSSION}

The incldence of fish or shellinsh-bone parasitic disease of zoonolic importance varles greatly between areas depending on food habits of peoples, and micro and macroclimate of the environment. Many specles of trematodeg jnhabiting insh or shellnsh as larval stage aie capable of causIng infections and diseases In human beings (WHO, 1996). Moreover, fish and shellnsh migh I, ic carry in their body some protuzoal agents transinlssible to the human cunsumers.

l'able (1) sliuws the occurrence and intensity of lifection with encysted niekacercartae in sliell. nsh at Sharkla. El-Isulalla and Port-Sald Provinces. "I he Infectlon ralc of cncyslcd metacercarjae in examined crayllsh at Starkla Provfnce was $79.9 \%$. Nearly shullar percentages of Infection of trematodes metacercarlac in Idver Nile Tresh waler lishes were prevtously rejorted by EL-Dally (1988) and saba (2004). Lower Incidences were also clled by 8halaby (1982), EL-Arougsi (1884) and Tantapy (1993). On the other hand. higher percentage (100\%) was recorded in Mugll sp. In Egypt by Rifant et al. (1980). Prevlous studles revealed llat lie rate of metacercarlae urectlons in M. cephalus. T. zlll1 and C. Lazera were $72 \%, 86 \%$ and $88 \%$, respecllvely as reported by EL-Dally (1888). Whereas, EL-Goharg and Samaba (1997) recorded Unat llie Infection rales of encysled metacercallae in Oreochronds sp. and C. Lickera were $72.9 \%$ and $68 \%$. It was cvident from the results recorded in table (1) that the total number of metacercarlac was 5911 metace-carlae. alld ranged from l-30 with an average of 6.4 per infecled crayllsh. These metacercanae were belonged to Jainllies Helerophyidae. Eclinostoinalldae. Cyathocotylidae and MIcrophallidae, labie (1) and figures (1-5). Fahmy et al. (1976) reported that the Incidence of encysted metacercarlae of Pruhemlstomum vivax and Haplorchis yokogaw In Rlver-ivile Inshes was ranged from 60 10 90\%. Shalaby (1985) observed an infection rate of $72.85 \%$ of Helerophyidae and Prohemistominae metacercartae In catish, C. Lazera collected from River Nile at Giza and Calro Provinces.

The occurrence and intensity of infection with metacercarlae in examlned shrimps and crabs at different Provinces are shown in table (1). It was found that the overall infection rate of encysted metacercarlae in the examined shrimps was $52.06 \%$. Nearly simular results was obtained in marlne fish by Abdel-Maksoud (1992). However, lower ggure was previously recorded in grass shrimp. Palmonete vulgaris by Pung et al. (2002). It Is clearly obvlous from the results recovered in lable (1) that the total number of metacercariae was 2514, and ranged from $1-25$ ivitli an average of 9.04 per infected shrimp. The Infectlon rate of encysted metacercariae in shrimps col- 
lecled from Zagazig nslı narkets was $48.76 \%$, (tablel). These metacercarlae were belonging to family Heterophyidae after identuncation of metacercarlae as well as adult worms recovered from experlinental Infecton. Meantine, the rate of metacercarial Infection in shrimps collected from EL Ismalla Province was 54.04\%. These metacercariae were belonging to famlles Heterophyidae, Microphallidae and Cyalliocotylidae. At Port Sald Provnce. the Infection rate was $52.87 \%$, table (1). and the types of recovered metacencarlae were belongling to famlles Heterophyidae and MIcrophallidae. The degree of salinity of water in each locality may be affect on the infection rates of white shrmps with metacercartae as was previously confrmed by Pung et al. (2002) who stated that the salinity preference of the paraslte's snall host have an inpact or effect on the infectlon rate with encysted metacercariae.

Concerning the occurrence and intensity of metacercartal infectlon in crabs at dinferemt ProvInces. table (1) illustrates that the overall infecuon rate of crabs was $38.7 \%$. Nearly slrilar per. centage was obtained by Moyou et al. (1983) who found that the infectlon rate of crabs with metacercarae of Paragonlmus $5 \mu$. Was $45.4 \%$. Lower percentages were prevlously obtalned by Raef et al. (1999) and Suglyama et al. (2004). it was evident from the results recorded in table (1) that the lotal number of metacercartae was 431, and ranged from $1-7$ will an average of 2.24 per Infected crab. (Igure 6). In one study carrled out In Sharkla Piovlnce. Egypt, Raef et al. (1989) found that the number of metacercartae per Infected crab was ranged from $2-45$ wh an average 13.8 per crab. However, in another study cartied out In Japan, Suglyama et al. (2004) fousid that the runiber of inetacersarlae per infected crab was ranged from 1-190 wills an aver. age 13.1. Table (1) clarifes that the infection rate of encysted metacercariae in crabs collected fron Zagazig was 28.28\%. Meanume, at ELIsmalla Province. the cate of melacercarial Infection in crabs was $43.9 \%$. However, the infectlon rate of metacercarlac was $42.85 \%$ in crabs collected from Purt Sald. (table 1).

From the results lecorded in the present study, one could be easlly deduce tlial the higliest Infection rate was in crayish followed by that in shrinips and lastly in crabs. The variations in the percentages of infectlon may be attributed to the water habltats elther fresh or marine and to Whe difference in localities of collection of shellinsli samples. Fresh water inay be polluted with sewage which may contain different eggs of trematodes. In addition, craynsh. Procambarus clas$\mathrm{kJl}$ is a voracious snall predator and it conpete with snalls by consuming aquatic planis used by snalls as refuge, oviposituon and food. Moreover. fresh water crayflsh posslbly eat the fry and the young Ish. so. crayfisl may acquire the infection and act as a paratenlc or transport host. This explanation was also conflnted by Raef (1994) who reported that the metacercarial infection in marne fishes was lower tliar that in Tresh water llshes. this is allributed to higiter water pollu. uon with humbis and anlnial excreta in fresh water than that in marthe water. On the othel 
hand, the lowest infecton rates detected in shrimps and crabs may be attributed to the Industrial or chemlcal pollution of marine water, having an effect on the intermedlate host snatl or free llving stages of parasites.

Regarding the seasonal prevalence of encysted melacercarlae in examined crayflsh, table (2) clarifies that the peak of infection (93.79\%) was in summer followed by spring (75.6\%), autumn (74.9\%) and lowest one was observed in winter (27.27\%). These results are nearly similar to the results of prevsous work of Tantawy (1893) and Saba (2004) who recorded higher incidences of metacercarlae in summer season in fresh water fishes. However, a lower percentage of infection was recorded by Raef (1994). Seasonal prevalence of encysted meluccrcarlae in craynsh deprind

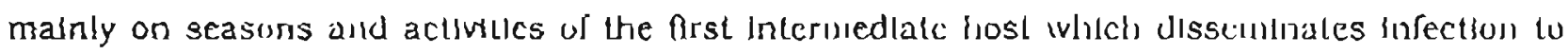

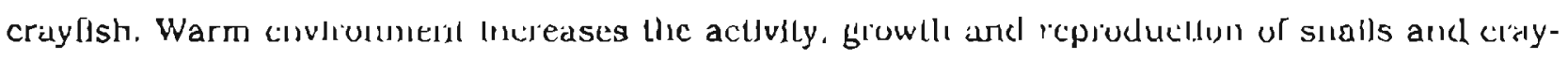

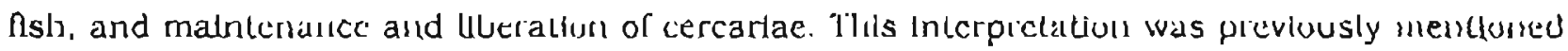
by Shalaby (1982)

Table (3) and 1ggures (2-5) Indicate that the melacercariae lufecting fiesli water crayfish and white shrinps were able to develop into thelr adult stages. From the melacercarlae infecung fresh water crayfish, 82 adull trematodes were dcveloped, where Heterophyes aequalis (23.1\%). Pygldiopsls summa (20.7\%), Centrocestus cuspldatus (15.8\%). Metagonimoides oreganesls (7.3\%). Microphallus uninus (9.7\%). Pro'tetristomum v(vax (12.2\%) and Petasigar skrjablı (10.9\%) were idenuned. Fim the metacercariae Infecting while shitinps. 74 adull tremalodes were developed. Of these trematudes, $H$. aequalis $(24.3 \%)$, P. genata (18.9\%), Centrocestus cuspidatus (21.6\%). Micropliallus minus (21.6\%). Martitema kitanesis $\{4.05 \%$ ) and Prohemisiomald sp. $(9.4 \%)$ were collecled (Lables 3 ). In the present study, all developed trematodes recovered from pupples expermentally Infected with metacercarlae were belonged to 4 famllles, Helerophyldae (H. aequalls, P. surnma, P. genald, Centrocestus cuspldatus and Metagonimoldes oreganesis). family Microphallidae (Mscrophallus minus and Maritrema kitanesis), family Cyathocotylidae (Prohemistomum vivax and Prohemistomalld sp.) and family Echlnostomalldae (Petasigar skrjabinf). Fahray et al. (1976) Idenufed P. vivax and Haplonchis yokogawl from pupples and kittens fed on inetacercaniae infecting fishes. Rthat et al. (1980) recovered $H$. heterophyes. P. vivax and Haplorchls yokogaw from pupples fed on fishes carrylng metacercarlae. Massoud et al. (1981) found that the infection rates with belerophyld worms were $2.56 \%, 0 \%, 33.3 \%$ and $14.28 \%$ in stray dogs. cats, red foxes and golden jackles. respectuvely. Shalaby (1982) obtained P. vivax and Centrocesius sp. after feeding of dogs on heavlly infected nshes with metacercartae. EL Aroussl (1984) recovered $H$. heterophyes, P. genata and Mesostephanus appendiculatus after feeding dogs on metacercarlae infecung C. Lazera. Shalaby (1985) detected four trematodes (Haplorchis punillo, M. appendiculatus, P. vivax and Cyndiplostomum azimi) In Intestine of dogs af- 
ler experinentad infection with metacercarlae In catnsh. EL-Dally (1988) oblained 5 flukes of zoonollc imporlance after expertinental infection of dogs with inelacercartae infecting fislies, and worns were Identhled inlo Haplorchis pumliso, P. genata $M$. appenticulatus, $P$. vivax and Centrocestus armatus in sinall intestine of birds after experimental infectlon with metacercarlae re covered from Tllapla sp.. C. Lazera and B. bayad. Tantawy (1993) idenufled P. genata. P. vivax. Procerovum caderoni. Haplorcbls pumllio and $M$. appendlculalus from experimentally Infected klttens, rats and plgeons with metacercarlae Infecting fresh water Iishes. Raef (1994) obtained P. vivax, M. appendiculatus and M. burmanicus after experimental Infection of pupples. chick. ens, ducks and albino rats with metacercartae infecting marne fishes. Fayek et al. (1997) Isolated Microphallus mlnus and Maritrema kitanesls after leeding ducklings on metacercariae lnrecking while shrimp. Saba (2004) obtalned $H$. heterophyes, $H$. aequalis, P. vivax and other different types of trematodes after orally administrating the metacercarlae in fresh water fishes to pupples, chickens and ducklings.

It is evident from the obtalned results that the experimentally infectch pupples will metacercartac oblained from crabs did not develop into adult worms, table (3). However, Raef et al. (1989) detected egg of Paragoninus kellicotu in feces of puppies as well as inmature worm in abdominal cavlty after experimental Insecuon.

Shelinsh can recover and concentrate environinentally dertved water patlıogens and can be used for the saultary assessinent of water qualliy by the detectson of Cryptosporidlun and Glardia in thelr tissues (Graczyk et al., 2001). Table (4) and ngure $(7 \Lambda, B)$ show the occurrence of protozoa oocysls or cysts in examined crayllsh at Sharkla Province. The lifection rates of crayIish will Cryptosporldium parrum oocyst and Glardla sp. cyst were $9.29 \%$ and $4.77 \%$. respeclively. Lower results were oblatned by Raef et al. (2003) who reported that tie infection rate of craynsh wiUn C. parvun oocyst was 6\%. Niso. Uiese results were higher than llat found by Fayer et al. (2003) who detected that the Infectlon rate of oysters and clams with Cryptosforldum oocyst was $3.7 \%$. Moreover. Slam et al. (1994) found an infection rate of $20 \%$ of Cryptosporddum oocyst in Nule crocodile. Glardia sp. cysts were previously detected from differen shellfish types by Graczyk et al. (1989) and Graczgk et al. (2003).

In the present study, all examined shrimps and crabs were negatve for Cryptosporidlum oocyst and Glardia cyst. Thls may be attributed to the extent of pollutlon of inarine water (habltat of crabs and shrimps) with anlmal or human sewage less than that in river water (habltat of craynsh). Moreover. the slow movement of fresh water in nver tributanes. where crayfish collected, helps in settling of Glardla sp. cyst in the sediment or different canals. Since, the behaviour of crayllsh is the burrowing in the sediment. so. these craynsh may (ake the tnfection with protozoal agents. Thls explanation was supported by Graczyk et al. (1999). 
It is precede to investigate the possiblity of experimental infection of warm-blooded animals with Cryptosporidium and Giardia tsolates recovered from fresh water craynsh to verify its zoonouc importance. In the present study, experimental infection of nve white albino rats with $\mathrm{C}$. parvum oocyst reveals that four rats $(80(1,1)$ ure infected with Cryptosporddum. One rat shed the oocyst in their faecal pellets at $3^{\text {rd }}$ day posunfection (PI), meanwhile. the remainder three rats descend C. parum oocyst In thelr faecal pellets at $5^{\text {th }}$ day $P l$, (ngure $7 C$ ). Inlected rats shed Cryptospondlum earlier than that observed by Raef et al. (2003) who found that experimentally Infected rats shed C. parvum oocyst In their faecal pellets at $6^{\text {th }}$ day PI. On the other hand, Amin et al. (1893) detected that experimentally Infected cathsh with Cryplosporidium oocysts of human origln shed the Infectlve agent in Its faces at $3^{\text {rd }}$ day $\mathrm{Pl}$.

Regarding 10 the experinemlal infection of two pupples with Glardla sp. cyst, it was notlced that all expenmentally infecled pupples shed Glardla sp. cyst In thelr lcces at $7^{\text {th }}$ day Pl. Hewlett ct al. (1982) experimentally infected mongrel dogs with cysts or (rophuzolte of G. Lamblia. Moreover. Amla et al. (1993) established an experimental infecluon of calish with G. Lamblia cyst of human orgln, the authors found that catnsh shed G. Lamblla cyst at $5^{\text {th }}$ day PI.

In the present study, histopathological sections were taken from small incestine of experimentally infected pupples with metacercarlae to determine the pathologlcal effect of aclult trenialodes. Figure (8. A to E) show adult heteruphyid trematodes in histopathological sections or smiall Intesune of experimentally infected pupples with melacercarlae obtained from crayllsh and shrimps. The adult heterophytd nukes, with Increased numbers of goblet cells and desquamated eplthelial cells together with Inflammatory cell infltration in the lamina propria of mucosa. were seen. These results were in agrcement with the Andings of Shalaby (1993). The effect of Cryptosporldlum parvum on rals and Gialda sp. on jupples were assessed by histopatiological examlnatsons. Figure $(9-\Lambda)$ revcals (lu: developmental stages of $\mathrm{C}$. parvum in histnpathological section of fleurn of experlmentally Infected rat with $C$. parvum oocyst obtained from craylish. The developmental stages of $\mathrm{C}$. parvum were seen In the brush border of the corrugated intesunal vull. these histopathologlcal finding agrees with that results obtalned by Reese et al. (1982) and Fayer et al. (1997). Figure (9-B) shows Glardla trophozolte in hislopathological section in Juodenum of experinientally infected puppy with Glardia sp. cyst from crayfish. This result was In agreentent with the nriding of Amin et al. (1993).

It could be concluded that, shellnsh (fresh water craynsh, while shrimps and blue crabs) were harbouring different types of trematode metacercarlae. These metacercarlae were developed after experimental Infection of pupples into adult worms of ten trematodes specles belonging to fow familles of Helerophyldae, Microphallidae, Cyathocotylidae and Echinostomaudae. All of these trematodes have a zoonoulc importance. Crayflsh showed higher occurrence us metacercarae 
than shdmps or crabs. The peak of Infecton in craynlsh was in sunmer season. The high level of trematode metacercarial infection detected in the present study. indicating the significance role of these cruslaceans as a potental reservoir for such zoonotic trematodes. In addition the higher Infection rates of craynsh with treinatode metacercarlae recorded in this sludy, reflecting the role of craynsh as a new host responslble for dissemination of such zoonotlc parasites. Moreover. Cryptosporidium parum oocysts and Glardia sp. cysts were detected in the examined crayfish. This would indicate the role which may be played by this type of crustacean as a source of these protozoal agents for shellnsh consumers and handlers. On the other hand, isolates of Cryplospordium and Glardia recovered from craynsh had established infectlons in rats and pupples. suggesting the possibllity of human Infection with these Isolates. Accordingly. perlodical parasit. olugical assays of edtule shelingh to clarify thelr santtary condition, avold coliection of slis:llish from areas with high Incldence of Infection, adequate cooking and eflclent hyglene practice durIng the preparation and evisceration of the shellfish. control of snalls with molluscicides where feasjble and avold contamination of aqualle environnent with raw human and anlmals sewage are the recornmended preventive measures tor the control of shelshsh-bune parasiuc zoonoses. 


\section{RESULTS}

Tuble (1): Occurrence and intensily of inlection wilh melacercariae in cxamined shellfish samples coilected from Sharkin, El-lsmalia and Port-Said Provinces.

\begin{tabular}{|c|c|c|c|c|c|c|c|}
\hline \multirow{2}{*}{$\begin{array}{l}\text { Type of } \\
\text { sleellfish }\end{array}$} & \multirow[t]{2}{*}{ Locality } & \multirow{2}{*}{$\begin{array}{l}\text { No. of } \\
\text { cxamined }\end{array}$} & \multirow{2}{*}{$\begin{array}{l}\text { No. of } \\
\text { infecled }\end{array}$} & \multirow{2}{*}{$\begin{array}{l}w \% \text { or } \\
\text { infecied }\end{array}$} & \multirow{2}{*}{$\begin{array}{l}\text { Tolal no. of } \\
\text { melacer- } \\
\text { cariae }\end{array}$} & \multicolumn{2}{|c|}{$\begin{array}{l}\text { 'robal no. of metacel- } \\
\text { corine per conylislı }\end{array}$} \\
\hline & & & & & & Range & Average \\
\hline $\begin{array}{l}\frac{\pi}{5} \\
\frac{5}{3} \\
\text { है }\end{array}$ & Sliarkin* & 1153 & 220 & 79.9 & $5911^{1 .}$ & $1-30$ & 6.4 \\
\hline \multirow{4}{*}{ 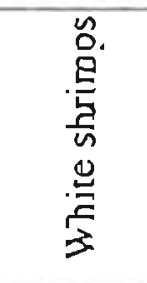 } & Sllarkia & 162 & 79 & 48.76 & $684^{+4}$ & $1-16$ & 8.6 \\
\hline & EL-Ismalia & 198 & 107 & 54.04 & $856^{4+7}$ & $1-24$ & 8 \\
\hline & Port Suid & 174 & 92 & 52.87 & $974^{++1+t}$ & $1-25$ & 10.59 \\
\hline & Tulal & 534 & 278 & 52.00 & 2514 & $1-25$ & 9.04 \\
\hline \multirow{4}{*}{ 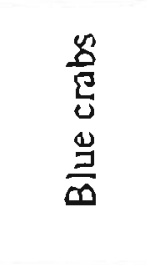 } & Sharkia & 152 & 43 & 28.28 & 108 & $1-4$ & 2.5 \\
\hline & El_-lsmalia & 148 & 65 & 43.9 & 154 & $1-5$ & 2.36 \\
\hline & Port Said & 196 & 84 & 42.85 & 169 & $1-7$ & 2.01 \\
\hline & Total & 496 & 192 & 38.7 & 431 & $1-7$ & 2.24 \\
\hline
\end{tabular}

Crayrish were collected frum difTercull canbls of Zngazig. Abokebeer. Ilehín nnd Menia EL-Kamah al Shan'kis Province

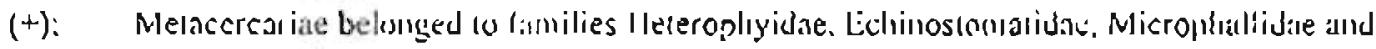
Cyillioculylithe.

$(++)$ : Melscercariae belmiged to Ianily theceroplyyidae.

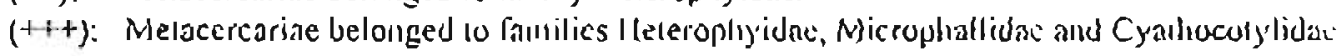

$(++1+)$ : Melacercariue belonged co lamilies I leceronhyidoe and Micropsnilidiae.

Tiable (2): Seusomal prevalence ol the encysted melacercariale in examineci cray fish ul Sharkia Province.

\begin{tabular}{|l|c|c|c|}
\hline \multicolumn{1}{|c|}{ Seasours } & $\begin{array}{c}\text { No or } \\
\text { examined }\end{array}$ & $\begin{array}{c}\text { No. of } \\
\text { infecied }\end{array}$ & $\begin{array}{c}\% \text { of } \\
\text { infecied }\end{array}$ \\
\hline Spring & 373 & 282 & 75.6 \\
\hline Summer & 403 & 378 & 93.79 \\
\hline Auruins & 331 & 248 & 74.9 \\
\hline Winler & 44 & 12 & 27.27 \\
\hline Tolal & 1151 & 920 & 79.93 \\
\hline
\end{tabular}


Table (4): Occurrence of protozoa oocysts or cysts in fresh water crayfish samples at Sharkia Province.

\begin{tabular}{|l|c|c|c|c|c|c|c|}
\hline \multirow{2}{*}{$\begin{array}{l}\text { Type of } \\
\text { shellfish }\end{array}$} & $\begin{array}{c}\text { No of } \\
\text { examined }\end{array}$ & $\begin{array}{c}\text { Cryplosporidium } \\
\text { parvum oocysts }\end{array}$ & \multicolumn{2}{|c|}{$\begin{array}{c}\text { Giardia sp. } \\
\text { cysts }\end{array}$} & \multicolumn{2}{|c|}{ Total } \\
\cline { 2 - 7 } & $\begin{array}{c}\text { No. of } \\
\text { infected }\end{array}$ & $\%$ & $\begin{array}{c}\text { No. of } \\
\text { infected }\end{array}$ & $\%$ & $\begin{array}{c}\text { No. of } \\
\text { infected }\end{array}$ & $\%$ \\
\hline Crayfish* & 1151 & 107 & 9.29 & 55 & 4.77 & 162 & 14.07 \\
\hline
\end{tabular}

* Crayfish were collected from different canals of Zagazig. Abokebeer. Hehia and Menia ELKamah at Sharkia. 


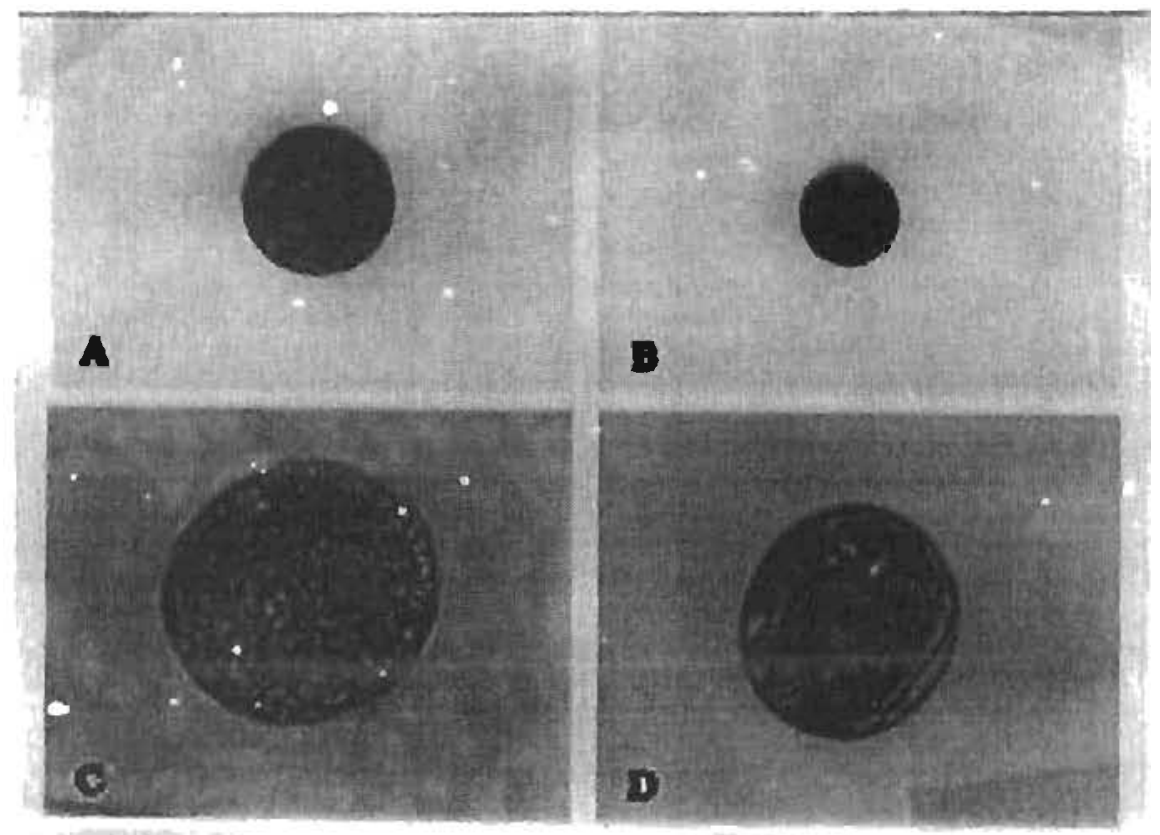

Ag. (1) : Helesuphld melacercarlae from trayfish and shrmps. A, B. D: (X100). C: (X400).
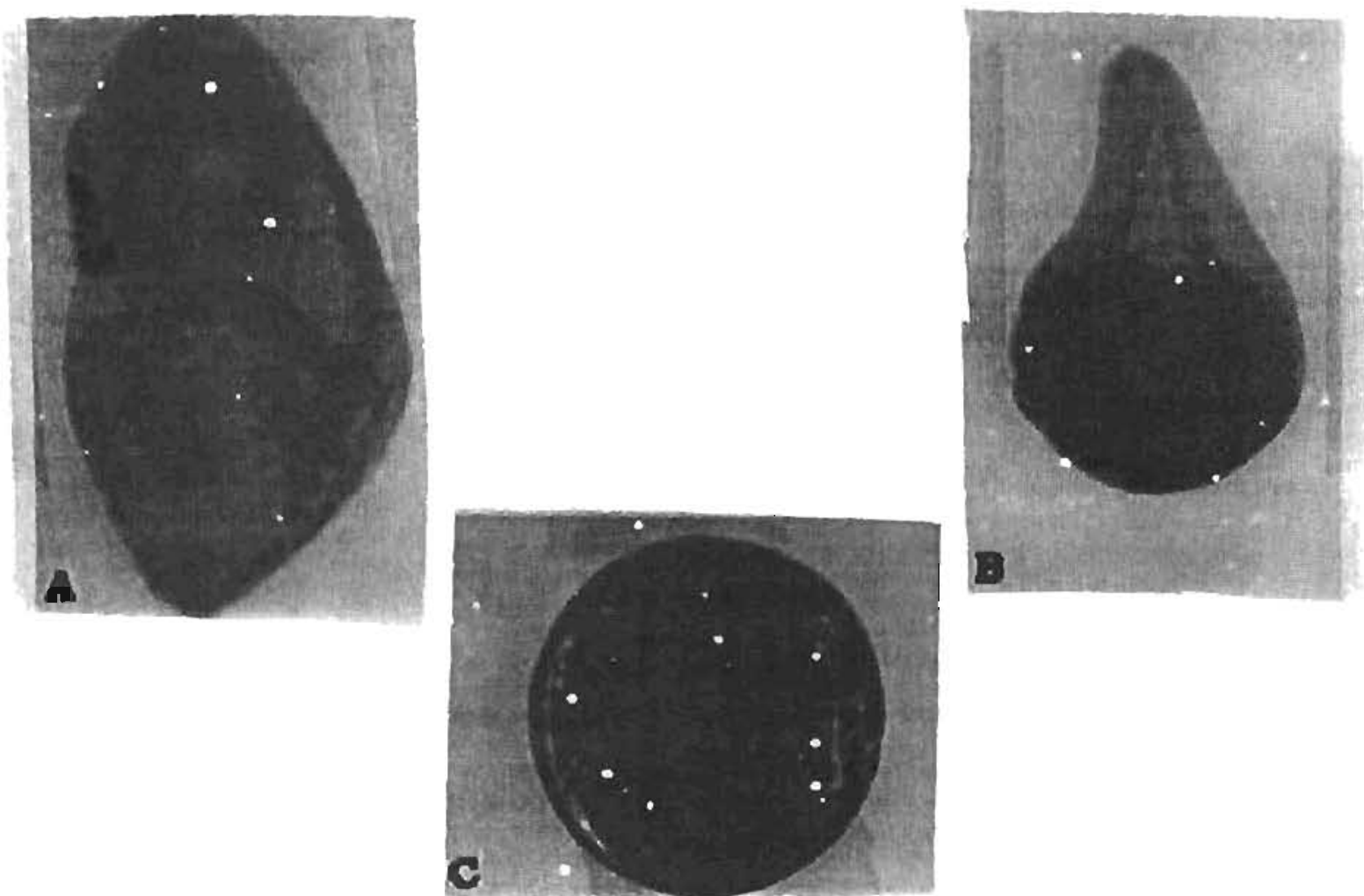

Fig (2): (A); ProhemIstoniun vivax, adult, X100. (B): Prohemislomicl sp., adult, X100.

(C); Cyahocolylld melacercariae from craylish and shrimps, X4nO. 

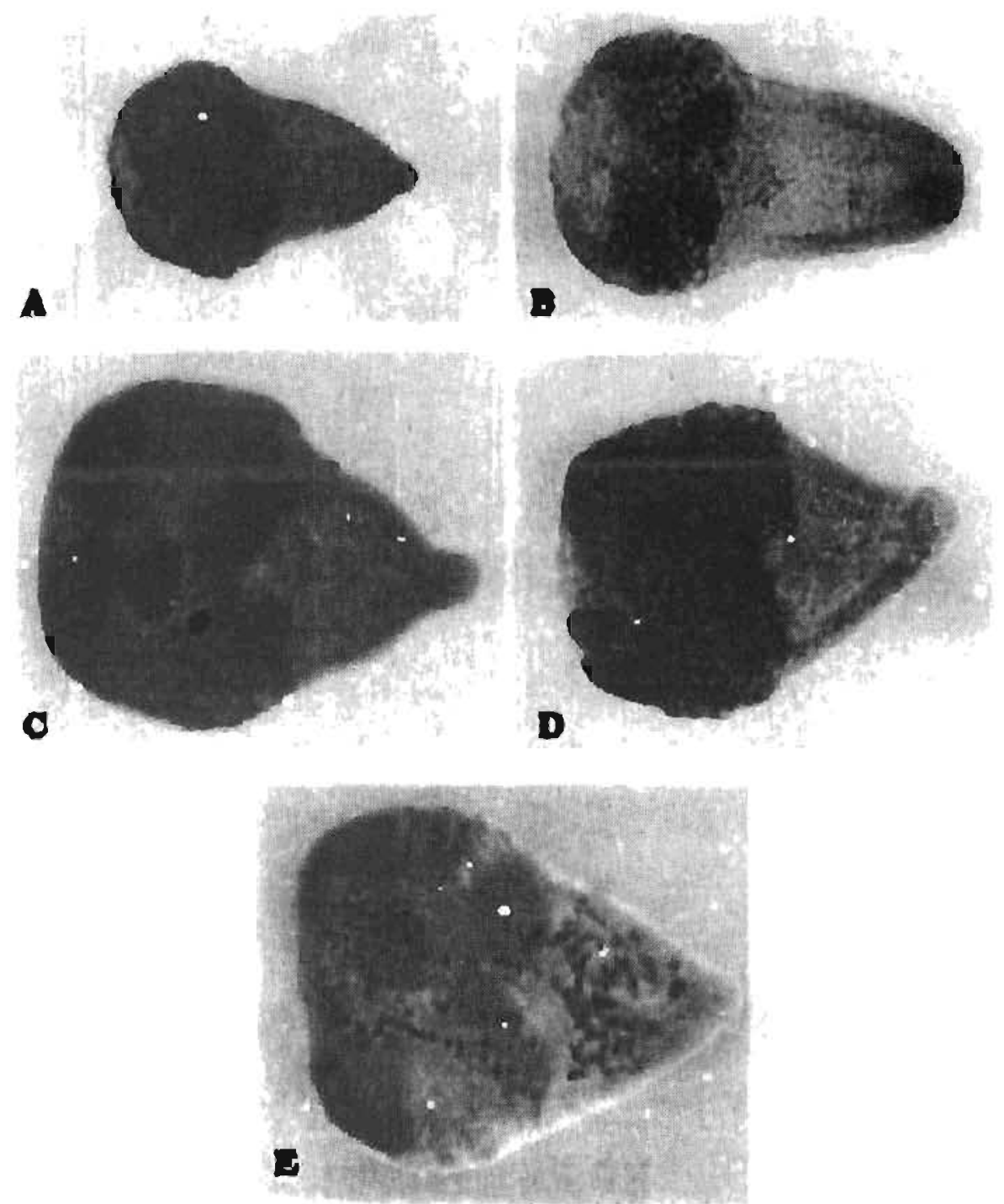

Fig. (3) : Adult helerophyld trematodes obtained from small intestine of experimentally infected puppies. (A); Heterophyes aequalis. X200. (B): Pygidlopsis summa, X200. (C); Pygidiopsis genata, X400. (D): Metagonomoldes oreganesis. X200. (E); Centrocestus cuspidatus. $\mathrm{X} 400$. 

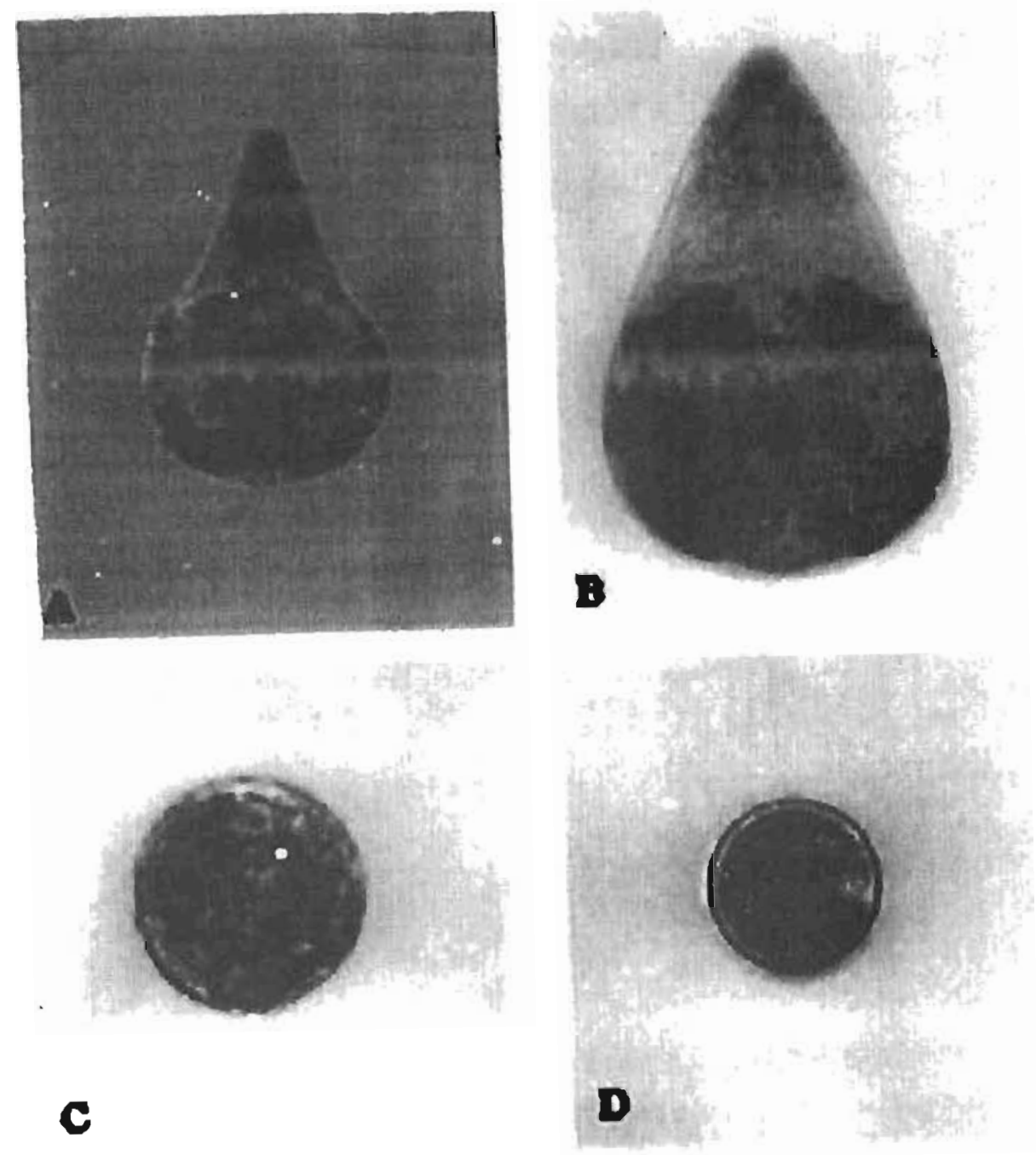

Fug. (4): (A); Microphallus ninus, adult. XIS.s. (B); Mlarttrema kilanensis, adult. X400. (CaD); Microphallid metacercariae. X100. 

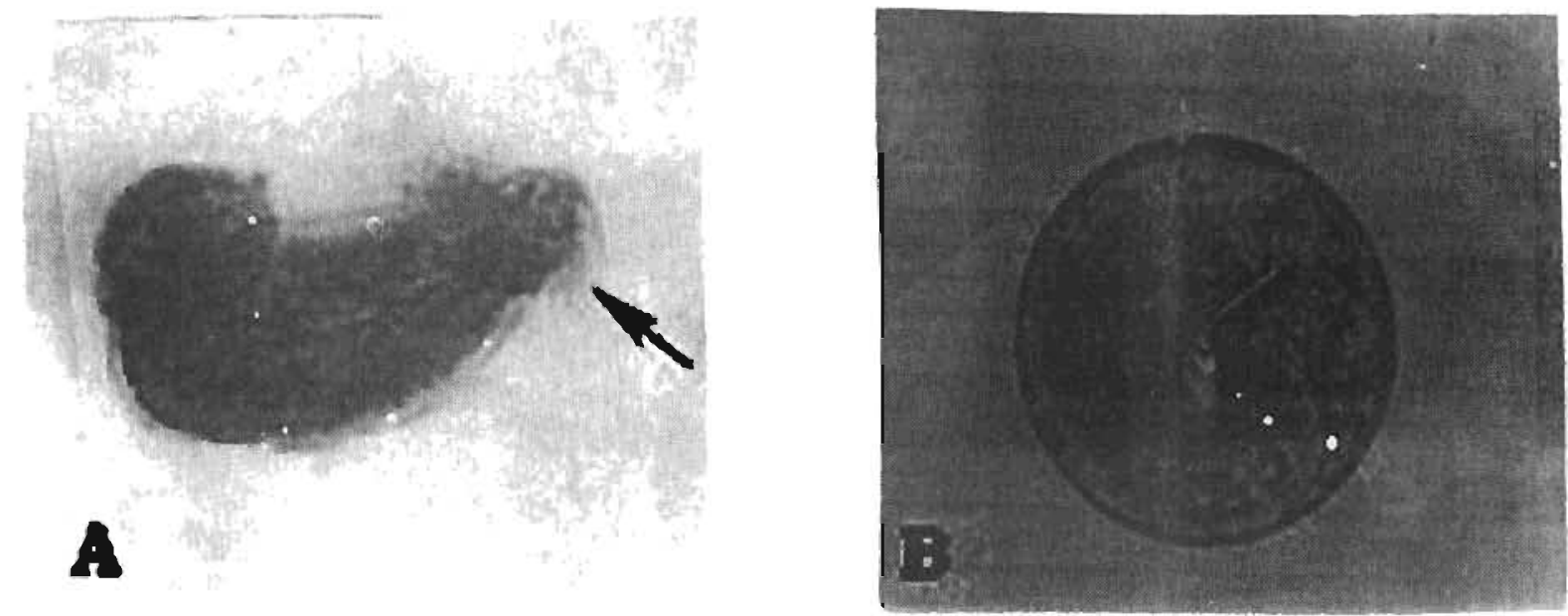

Fyg. (БA); Petaslgar sterjabinl, adull, X100.

(B): Eclunoslomatud metacercariáe. $\times 100$.
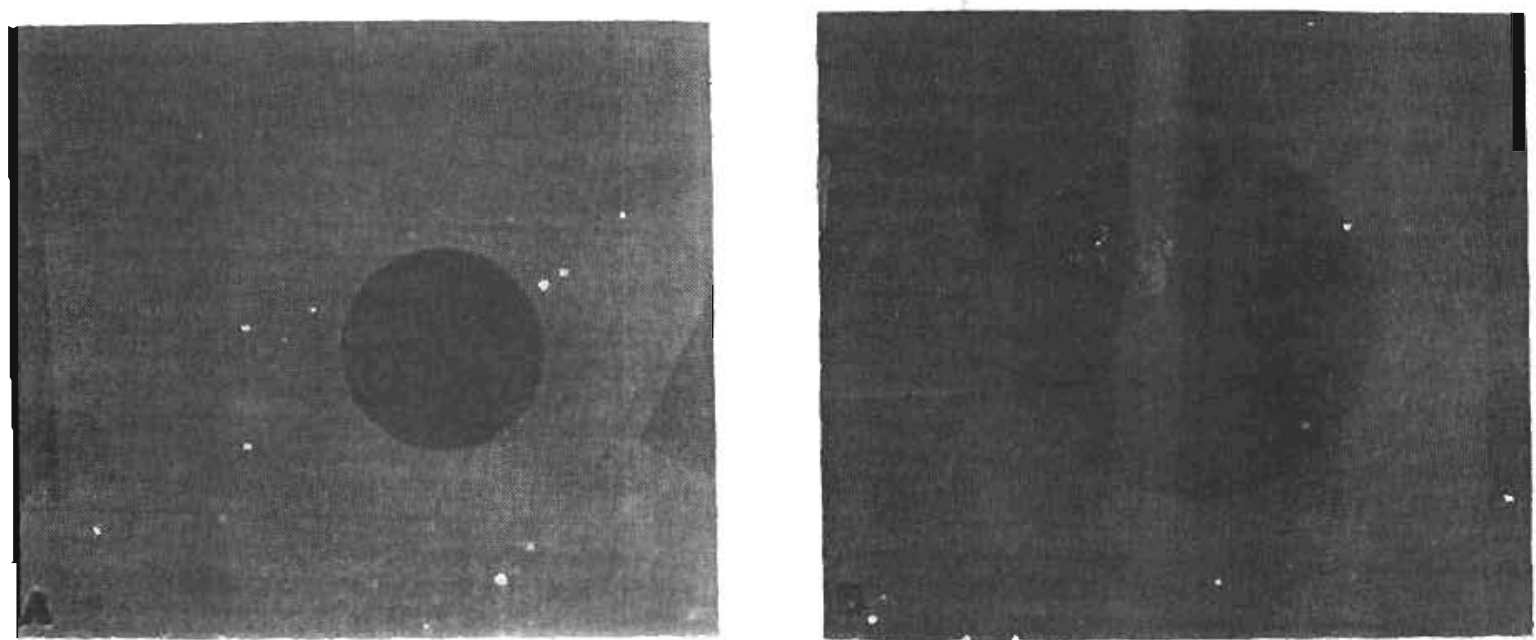

Fig. (6A \&); Encysled metarrercarlae obtalned from the gills of blue crabs X100.

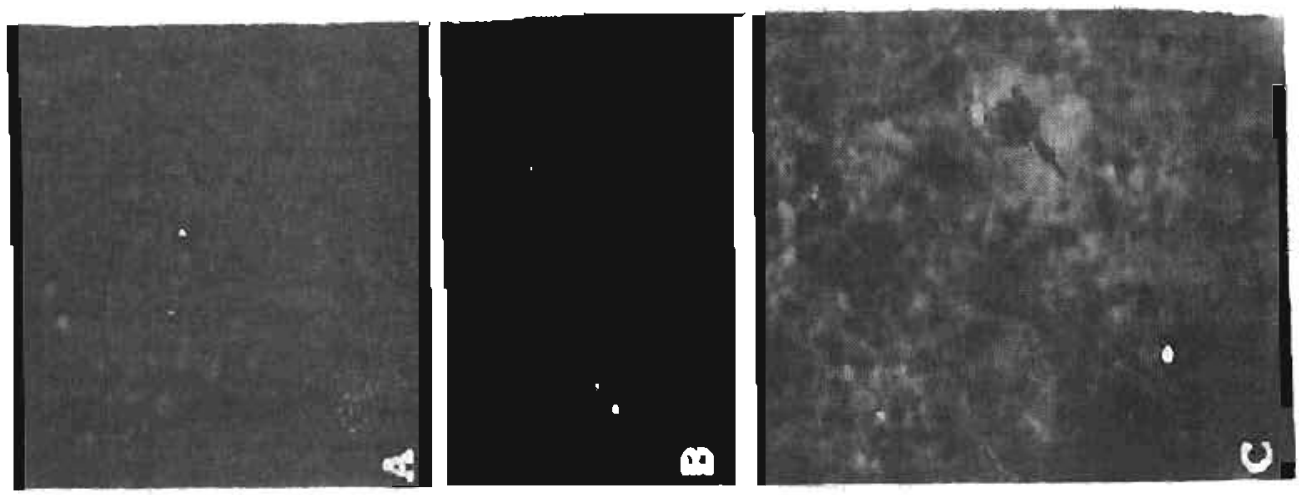

Fig. (7): (A): Glardia sp. cyst from craynsh (unstalned), X400. (B); Cryptosponidlum parvum oocyst from crayllsh (unstalned), X1000. (C): Cryptosporldlum parvum oocyst delected in rat faecal pellets (stalned by modiffed Zlehl-Neelsen technique). X1000. 

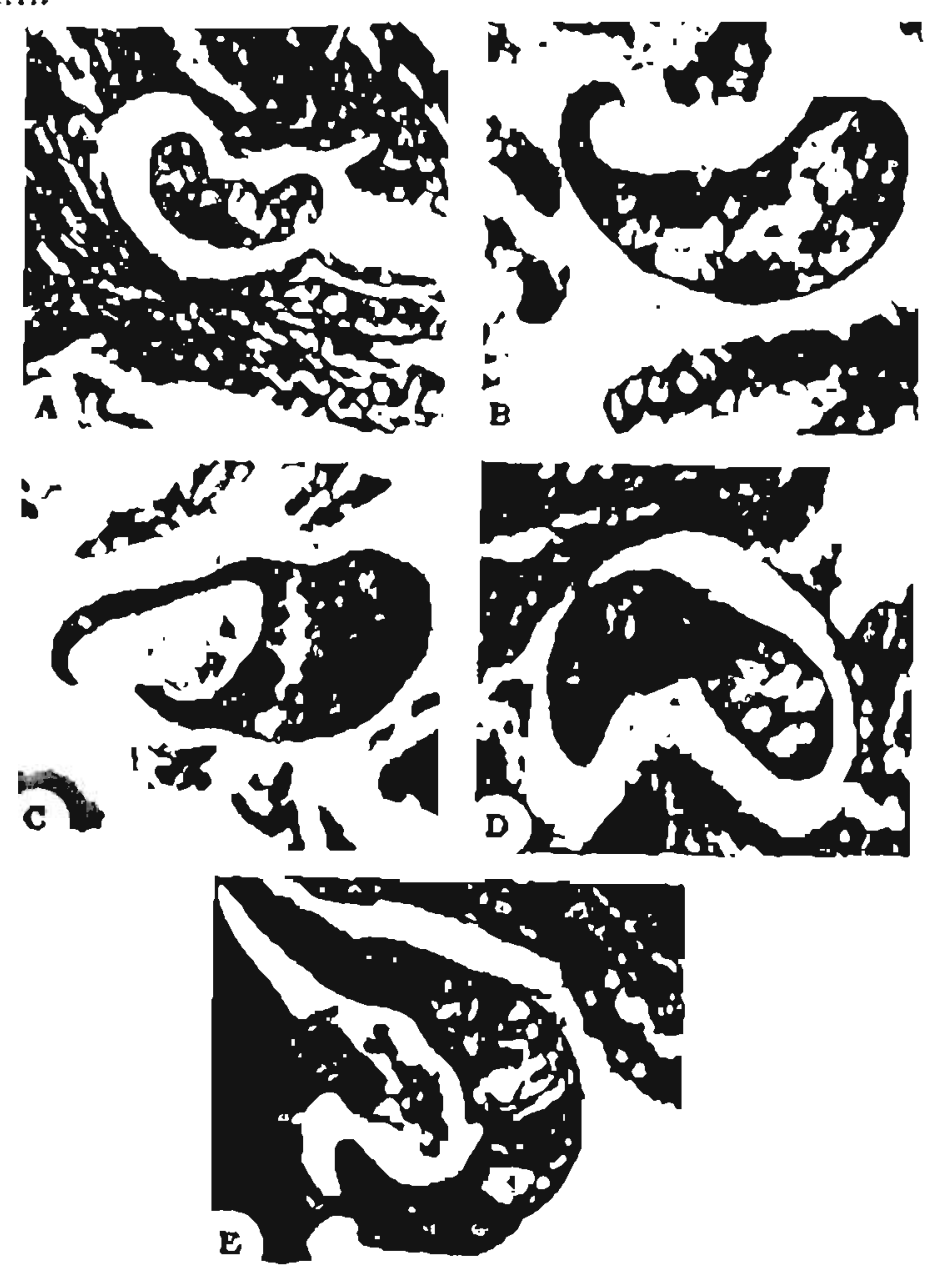

Fig. (8): Adult heterophyld trematodes in histopathological sections of sinall intesines of expermentally infected pupples wilh metacercarlae obtained from craynsh and shrimp (H\&E). X400.
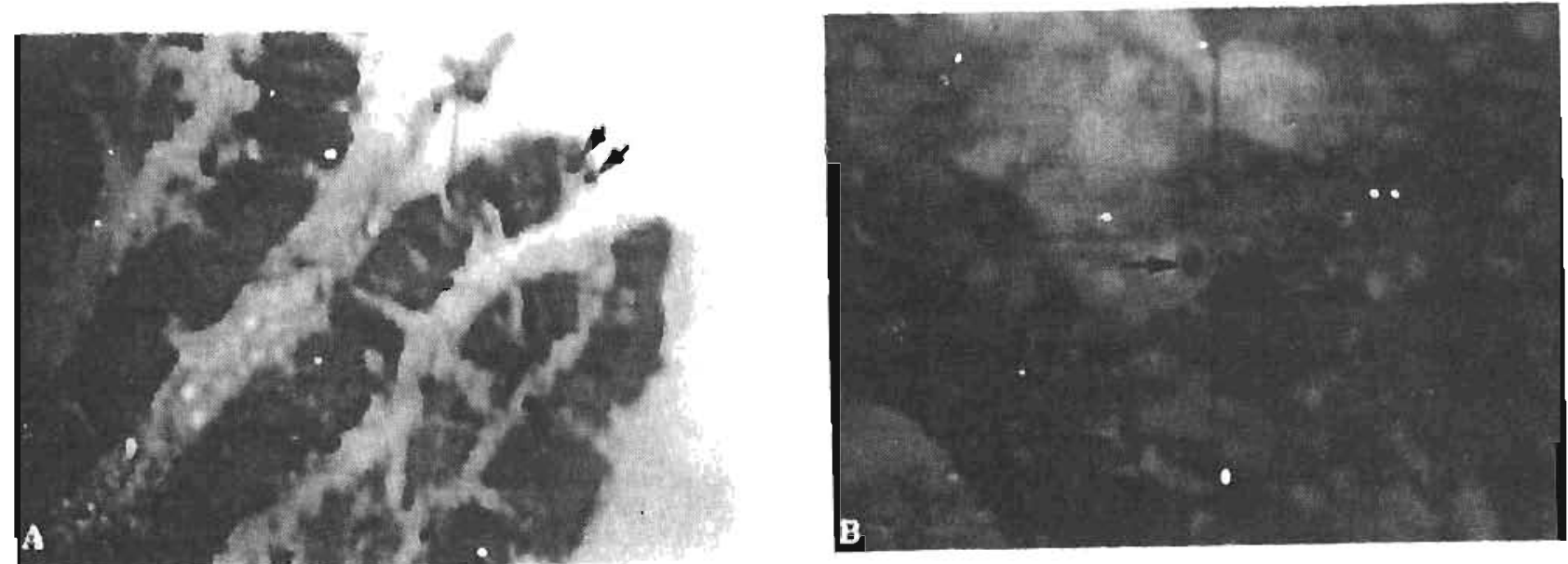

Fig. (9): (A): Developmental stages of Cryptosporidlum parvum in histopathological section in IIeum of experimentally Infected rat with Cryplosporldium parvum oocyst obtained from crayflsh (H\&E), X400. (B):Glardia trophozolte In histopatiological section in duodenum of expertmentally infected puppy with Giardia sp. cyst recovered from cray0sh (H\&E), X400. 


\section{REFERENCES}

Abd EL-Maksoud. 8. A. (1992) : Zounotlc agents In martne nsh marketed in Dumyat. M.V.SC. Thesls. Zoonuses. Tac. Vet. Med. Zagazig Unlv.

Abou-Basha, L. M.; Abdel-Fattah, M.; Orecchla, P.; Dlcave, D. and Zakl, A. (2000) : Epictemsological shidy of heterophylasis among humans. Eastern Mediterranean Health Jour. nal. 6(5): 932-938.

Amln, M. A.; Amer, O. h. and El-Attar, S. R. (1993): Studies on the role or nsh In transisiltting some zuonutic diseases. Zidg. Vel. J.. $21(3)$ : 414-429.

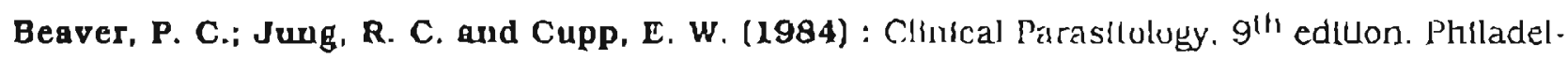
phla: Lea and l'eulgir.

El-Arousal. N. M. M. (1984): Menpholugh ail and blological sludles on some trematodes of fisheathg mannals with empirasls $m$ the role of flshes as sccond intermedlate host. M.Sc. thesis, Department ul Zoolugy, liac. Sctence, Cairo Univ.

EL-Dally, K. M. H. (1988) : The role of fislı as intermedlate host for (ransmling some parasites of zoonotic importunce, in Behera Governorate. M.V.Sc. Thesis, Meat Hyglene, lac. Vet. Med. Alexandria Univ.

El-Gohary, A. H. and Samalia. H. A. (1997) : Oreochromls spp. and Clarias lazera as a source

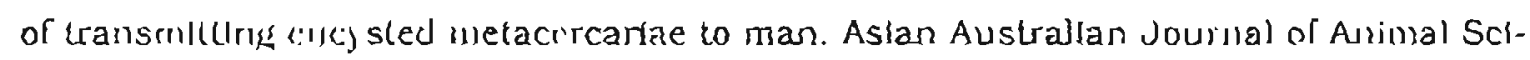
ences. $10(4): 439-443$.

Gatamy, M. A.; Manduur, A. M. and El-Naffar, M. K. (1976) : Successful In[ection of dugs and cals by Prohemistonum vlvix sonshno, 1893 and Haplorchls yukugawl Katsula, 1 j22. Jounal of the Egyptian Suclety of Parastlology, 6: 77-82.

Fayek، S. A. $\mathbf{\Lambda b d}$ EL-Waliab. $\boldsymbol{x}$. M. and Raef, A. M. (1999) : Nematode parasles of crayish (Prucambarus ciark(1) at Katr EL-Sheikh Provlnce. Alex. J. Vet. Sclence, 15\{1\}: 79-88.

Fayek, S. A. Raef, A. M. and Abd El-Wahab, T. M. (1997): Sume sludles on helininlly parasites encystation in Penacus seliferus (white shrimp) at Port Sald. Egypt. Zab. Vil. J., 25(3): 29-33.

Fayer, R.: Farley, C. A.; Lewls, E. J.; Trout, J. M. and Gracegk, T. K. (1997) : Putenlul role of the eastern oysters, Crassostrea virglnica. In the epidemlology of Cryptusporidium parvum. Applird and Environmental Mleroblology, 63(5): 2086-2088.

Fager, R.: Trout, J. M.: Lewig, E. J.; Santln, M.; Zhou, L.; Lal, A. $\boldsymbol{\Lambda}$ and Xlao, L. (2003): Conlamlnalion of Allanlic cuast commerclal shellnsh with Cryjulosporldsum. Parinitolo- 
gy liestarch. 89(2): 141-145.

Garcla, L. S. (2001) : Diagnostic Medical Parasitology 4th (Ed.) ASM Press. Washington, D.C.. U.S.A.

Graczyk, T. K.; Conn, D. B.; Marcogllese, D. J.; Graczyk, H. and Delafontadne. Y. (2003) : Accumulation of human watemorne parasttes by zebra mussels (Drelssena polymorpha) and Aslan fresh water clams (Corblcula fluminea). Parasitol. Res., 89(2): 107-112.

Graczyk, T. K. and H,ted, B. (1998) : Echinostomiasis a common but forgotten Sood-borne disease. Am. J. Trop. Med. Hyg. 58(4): 501-504.

Graczgk, T. K.; Marcogliese, D. J.; Delafontalne, Y.; DasUra, A. J.; Mangaml-Rưende, B. and Plenlazek, N. J. (2001) : Cryptosportdiun parvum oocysts in zebra mussels (Drelssena polymorphal: evldence from the ST Lawrence RIver. Parasllology Res., 87(3): $231-234$.

Graczyk, T. K.; Thompoon, R. C. A.; Fayer, R.; Adamg, P.; Morgan, U. M. and Lewls, E. J. (1999) : Glardia duodenalis cysts of genotype A recovered from clans in the Chesapeake Bay Subestuary Rhode River. Am. J. Trop. Med. Hyg., 61(4): 526-529.

Hal, Y. S. and Mott, K. E. (1994) : Epidenlology and morbidity of food-borne Intestinal trenatudes infections. Tropical Diseases Bulletin, 91 (7): RI26-R146.

Happich. F. A and Boray, J. C. (1969) : Quantilauve dlagnosis of clironic fasclolíisis 1. Comparatlee studles on quantitalive fecal examination for chronlc Fasciola liepatica infecllon in sheep. Aust. Vet. J. 45: 326-328.

Henrlksen, 8. A. and Pohlenz, J. F. L. (1981) : Stalning of Cryplusporldiun by a modifled Zlehl-Neelsen techrilque. Acta. Vet. Scand. 22: 495-496.

Hewlatt, E. L. J. A; Audiews, J.R.; Schaefer, F. W. (1982) : Expertmental infection or inungrel dogs with Glardia Lamblia cysts and trophozoltes. J. Infect. Dis., 145: 89-93.

Dorahlm, M. A. Khall, M. T. and Mobarak, F. M. (1995) : On the feeding betiavior on the exolle crayfish. Procambarus clarkde In Egypt and its prospects In the blocontrol of local vecior snalls. J. Union. Arab Biol. Calro. 4(A): 32 l-340.

Tbrahim, M. K.: Mahit,oud. Z. A. and Khalifa, R. (1989) : Pathological changes associated with Haplorchls pumilio (Looss, 1896); An Iittestinal tremalode of dogs. Assiut Vet. Med. J.. $21(4)$ ): 94-96.

sevine, N. D. (1985) : Vetcinnary Protozoology. Lowa Stale. Unlversity Press. Ames $1^{\text {st ed. }}$

Mahdy, A. O.; Ėsв, A. M. and Essa, 8. E. M. (1996) : Parasltologlcal and pathologlcal sludles 
on metacercarlal Infection in Tilapla sp. from Manzala, Egypt. Egypt. J. Comp. Palhol. and Cllnic. Prithol., 8: 131-145.

Massoud, J.; Jalall, H. and Reza, M. (1981) : Sludles on trematodes of the famlly Heterophyidae (Odhner. 1914) in Ігал: 1. prelunlnary epidemlological survey in man and carnlvores in Khuzestan. Journal of Hehininhology. 55: 255-260.

Moyou, 8. R.: Enyong, P.: Kouamouo، J.: Dlnge, J. S.: Couprle, B.: Rdpert, C.; Mogou-8omo, R. (1883) : Study of paragonimiasis in five village of the Departinent of Meme (SouthWesten Cameron). Results of Prazlquantel treatment. Revue-Sclence r.t-Technique. Sclence-Sante. No. 6-7: 125-129.

Pung, O. J.; Khan, N. R.; VIves, P. 8. and Walker, C. B. (2002) : Prevalishe, geographic disui uution and niness effects of Micropliallus turgidus (Trematoda: Mlciophallidae) In grass shrinp (Palaemonetes spp.) from coastal Georgla. Joumal of Parasltology. 88: 89-92.

Raef, A. M. (1994) : Rote of marlne nslı in transmission of some parasltes to anlmals and birds. Ph.D. Thesis. Parasikulugv. Fac. Vel. Med. Zagazlg. University.

Raef, A. M.; Mohamed, A. A. and Abd El-Maksoud, S. A. (1099) : Role of blue crabs "Calltnecles sabiclus" in transmisslon of Paragonlmus (lung fluke) to dog at Sharkla fish markets. Bcnl-Suef Vel. Med. J.. O(3-A): 299-309.

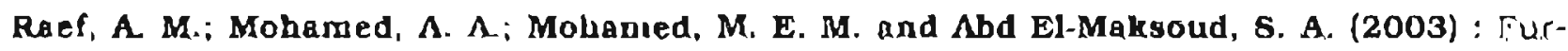
ther studles on lli: role of crayssht (Procambarus clarkj) in transmisston of some zoonoulc parasites in linst Della. The third Internallonal Sclenunc Conference. Mansoura, Fac. Vel. Med. Mansesura Unlv. 29-30 A prll, 2003, pp. 151-158.

Row1, M. S. (1095) : 'luxkcologlcal and pliysologlcal characterisucs of Aluminum in some fresh water mulluses and crustaceans. Proc. Zool. Soc. A. R. Egypl. 24: 229-243.

Reese. N. C.; Current, W.L.; Ernst, J. V. and Balley, W. S. (1982) : Cryptospurdilosis or man and calf; A case repurt and results of experimental Infections In mice anct rats. Anı. J. Trol). Med. Ilyg. : isl(2): 226-229.

Reld, W. M. (1962) : Chicken and turkey lape worm. Georgla Agric. Exper. Sta. Ahens Georgia.

Rurat, M. A.; Salem, 5. A.; El-Rholy, S. 1.; Hegazl, M. M. and Yousef, M.El-M. (1980) : Sludles on the lincidence of Heterophyes heterophyes In Dakahlia Governorate. Journal of the Igypuan society of Parasltology. 10 (2): 369-373.

Saba, S. E. R. (2004): Sume sludles on parasltes encystations of freshl water nshes. Ph.D. lliesis. Parasililogy, lac. Vet. Med. Zagazig. Univ. 
Shalaby, 8. I. A. (1982) : Studies on the role played by some Nile flshes in transnilting trema todes worms to dogs. M.V.Sc. Thesis, Parasitology. Fac. Vet. Med. Cairo Univ.

Shalaby, S. 1. A. (1986) : Further studies on the role played by some cat-nsh in transmitting some trematodes to flsh eallng mammals with speclal reference to the morphoblology of Mesostephanus appendlculatus. Ph.D. Thesis. Parasitology. Fac Vet. Med. Cairo Univ.

Shalaby, S. I. A. (1993) : Communlcable parasites from Nile nshes. II. Intesunal pathology In firal host induced by Haplorchid flukes. Egypt. J, Comp. Pathol. and Clin. Pathol., 6(1): 189-197.

Shlbahasa, T. and Nishlda, H. (1986) : Studles on the lung fluke. Paragonimus westermantDipluid tyue in the Northern part of Hyogopreffuture Japan. VJ. Expertmental oral tnfec. tion of a wild boars and pigs with the metacercarlae Jpn. J. Parasltol., 35(5): 427-431.

Blam, M. A.: Salem, G. H.; Qhonelm, N. H.; Mlchael, S. A. and El-Refay, M. A. H. (1994) : Cryptosporidta in Ectotherns and human contacts. Assiut Vet. Med. J. 32(63): 126130.

Suglyama. H.; Morlshlma, Y.; Kameoka, Y.: Aralkawa, K. and Kawanaka, M. (2004) : Paragoninus ohtrai metacercarlae In crabs collected along the Arakawa Rlver In 'Tokyo. Japan. J. Vet. Med. Scl.: 66(8): 927-931.

Tantapy, E. A. (1993) : Muscular parasltes In market nshes. M.V.Sc. thesls, Hyglene and control of meat. fish and thelr products and animal by products. Fac. Vet. Med. Cinlro. Univ.

WHO, (1985) : Control of food borne trematode infectsons. WHO Tech. Rep. Ser. No. 849. World Health Organlzation. Geneva, pp. 1-157.

Yamagutl, S. (1968) : Systema helminths. Vol. l. Olgenetuc tematodes of vertebrates. Interscience publisher, London. 


\section{دراسـات عن دور الأسـماك القشتر; زة كمصـدر لنتـل بعض الطفيليـات

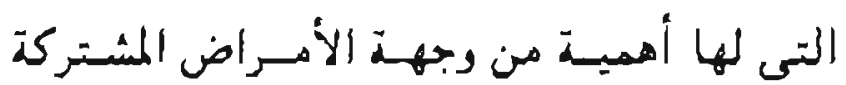

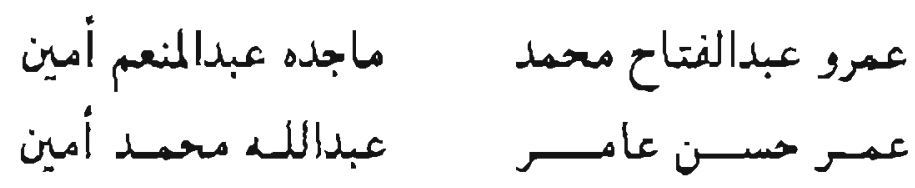

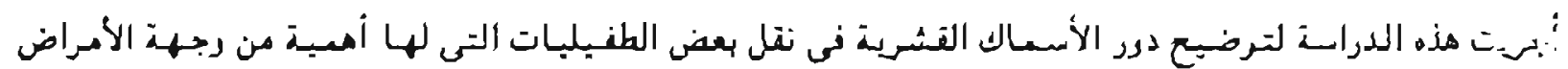

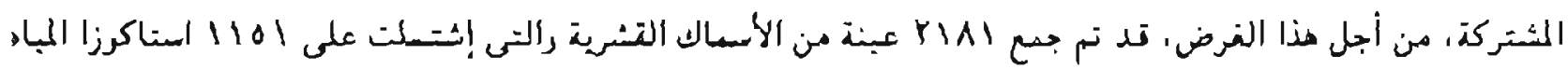

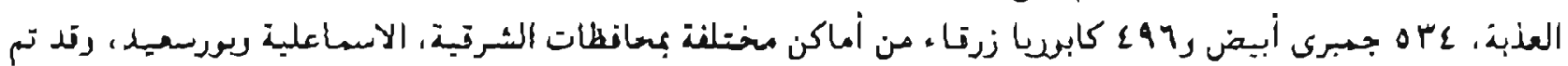

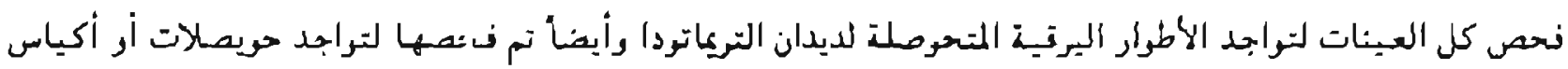

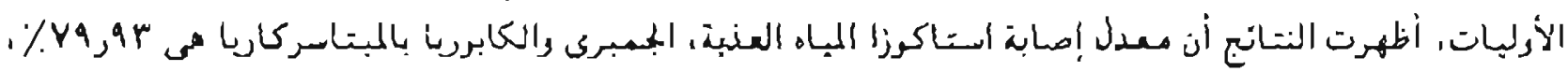

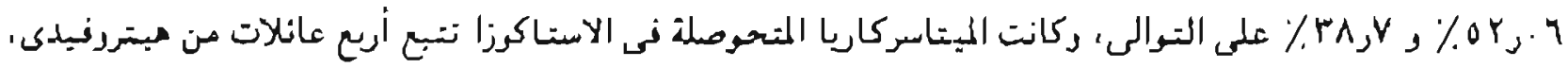

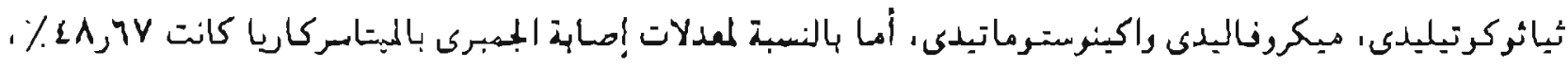

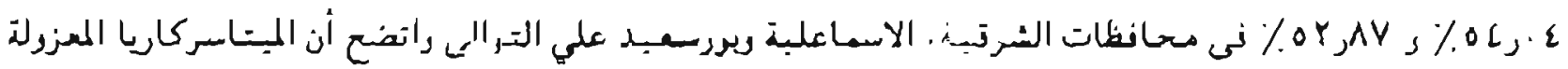

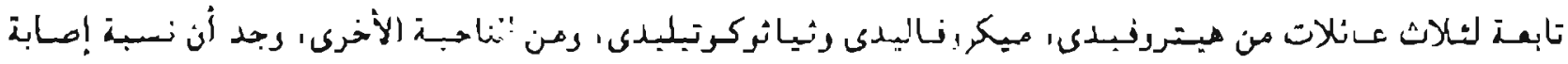

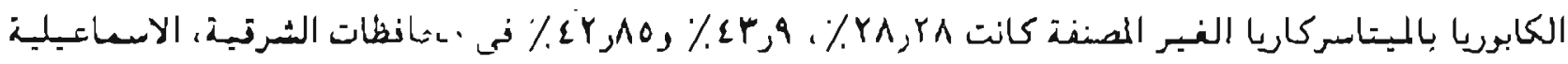

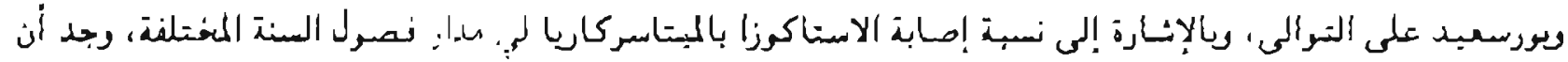

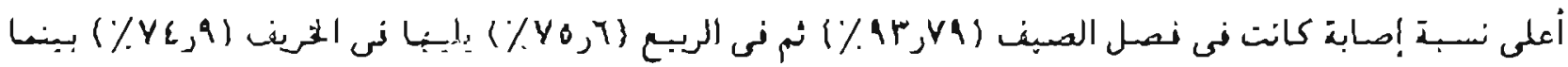

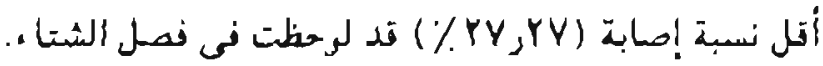

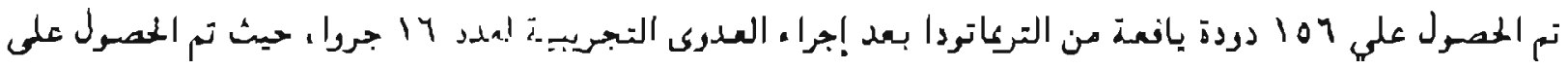

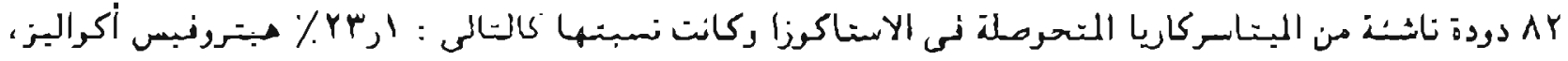

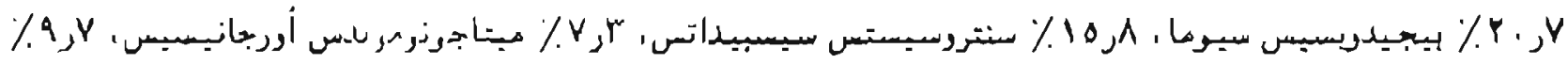

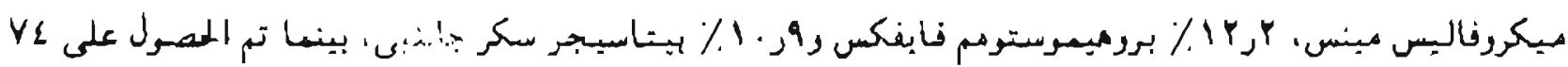

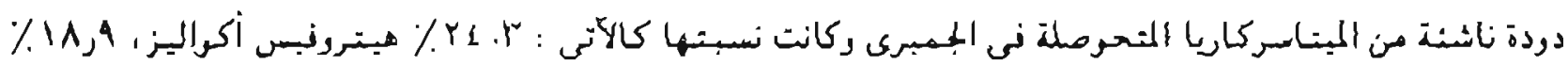

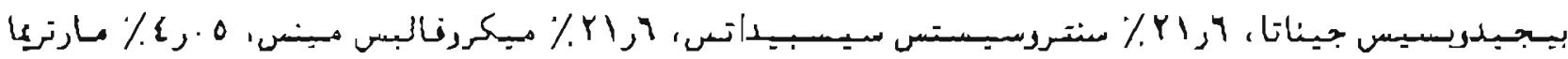

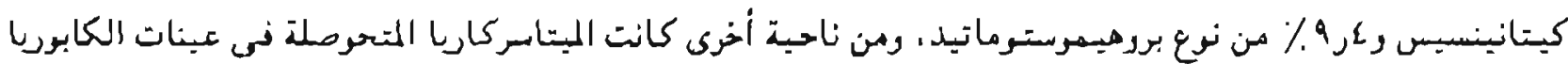

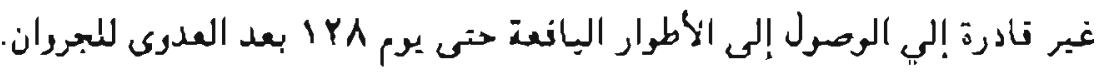

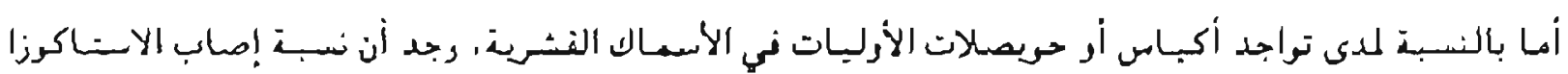




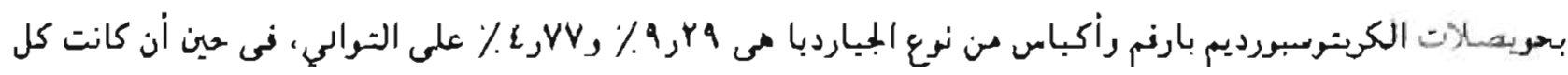

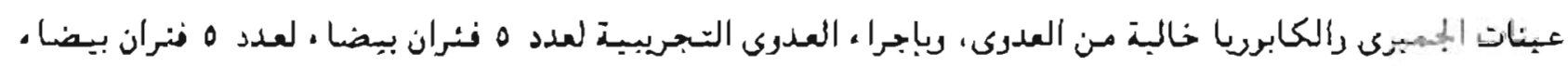

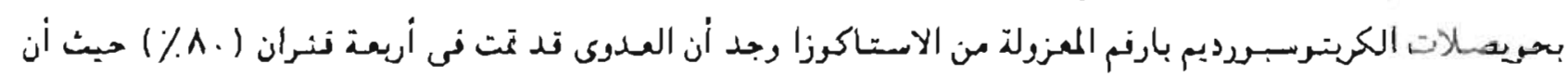

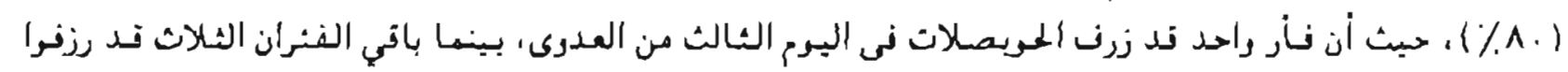

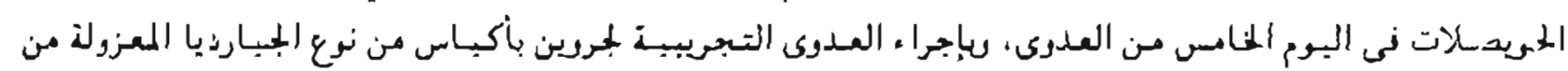

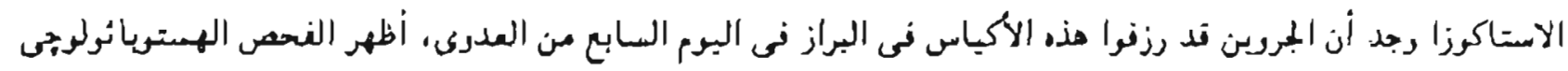

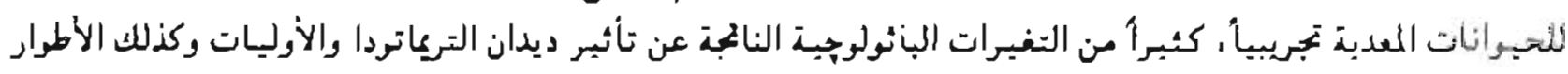

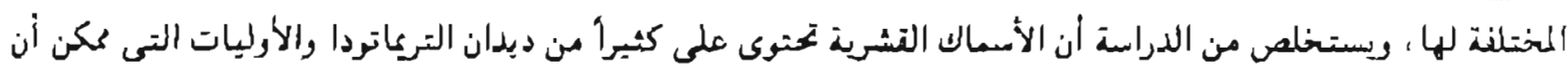

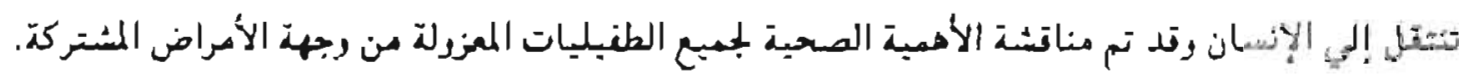

